\title{
The results of palaeontological excavations in the Sadowa Góra quarry (2012-14)
}

\begin{tabular}{|c|c|}
\hline $\begin{array}{l}\text { Dawid Surmik }^{12} \text {, } \\
\text { Sylwia Skreczko } \\
\text { Mateusz Wolny }\end{array}$ & $\begin{array}{l}{ }^{2} \text { Faculty of Earth Sciences, } \\
\text { University of Silesia, Będzinska Str. 60, 41-200 Sosnowiec } \\
\text { Institute of Paleobiology, Polish Academy of Science, } \\
\text { Twarda Str. 51/55, 00-818 Warsaw } \\
\text { dawid@surmik.pl }\end{array}$ \\
\hline
\end{tabular}

\begin{abstract}
Palaeontological fieldwork (2012-14) in the Sadowa Góra quarry carried out under the auspices of the University of Silesia, within the framework of a research project supported by the National Science Centre, helped to document the taxonomic diversity of Middle Triassic marine vertebrates from the Cracow-Silesia region. Accumulations of fossil bones are correlated with storm deposition and are time-averaged.
\end{abstract}

Key words: palaeontology, taphonomy, Middle Triassic, marine reptiles, Jaworzno

DOI: $10.2478 /$ ctg-2014-0027

Received: $30^{\text {th }}$ June, 2014

Accepted: $30^{\text {th }}$ October, 2014

\section{Introduction}

Palaeontological excavations carried out in the abandoned quarry of Sadowa Góra in Jaworzno (now the GEOsfera - Education Centre of Nature and Geology; 50 $13^{\prime} 38^{\prime \prime} \mathrm{N}$ $19^{\circ} 16^{\prime} 27^{\prime \prime E}$, Fig. 1A, B, see also Woźniak and Krzeczyńska 2014), led to numerous documented occurrences of remains of marine vertebrates, including the semi-aquatic reptile Nothosaurus. The bone-bearing beds, include the lower part of the Upper Gogolin Formation (Kowal-Linka 2008, and the literature cited therein), also contain numerous reptile coprolites (Fig. 1C).

In the Middle Triassic, the epicontinental sea of Germanic Basin was filled with different marine and semi-aquatic reptiles, such as ichtyopterygians, pachypleurosaurs, pistosaurs, nothosaurs and placodonts, and terrestrial tanystropheids and archosaurs (Surmik 2010a,b, and literature cited therein). The most of these animals lived in near-shore environment and over the time they conquered the open seas. The biological diversity of Middle Triassic aquatic reptiles is documented from several important localities of Southern Poland (Bardziński et al. 2008; Surmik 2010a,b, and literature cited therein; KowalLinka et al. 2014). The Sadowa Gora quarry is another fossil site that documents paleographical distribution as well as evolution of Nothosaurus genus.

\section{Geological settings}

The carbonates of the Lower Muschelkalk (Middle Triassic) Cracow-Silesian region have been the subject of interest since the second half of the nineteenth century (Kuźniar 1930; Assmann 1944; Siedlecki 1949). The first mentions of remains of prehistoric animals from the Jaworzno area were highlighted in Zeuschner (1836). Later works focused on lithostratigraphy and palaeogeography (Bojkowski 1955; Gruszczyk 1956; Ekiert 
1959; Aleksandrowicz and Aleksandrowicz 1960; Śliwiński 1964, 1969; Aleksandrowicz 1966, 1971a, 1971b; Wyczółkowski 1971; Kowal-Linka 2008; Kowal-Linka et al. 2014). Sedimentological studies have been rare (Bojkowski 1955; Bogacz et al. 1968; Kubicz 1971; Chudzikiewicz 1975, 1983). More recent works have debated Muschelkalk lithostratigraphy, mainly in the Opole region
(Niedźwiedzki 2000; Kowal-Linka 2008, 2009), and bio-, magneto-, and sequence stratigraphy (Zawidzka 1975; Hagdorn and Głuchowski 1993; Nawrocki and Szulc 2000; Szulc 2000; Narkiewicz and Szulc 2004). Based on isolated remains of crinoids and echinoids, Hagdorn and Głuchowski (1993) presented four biostratigraphic zones.

B
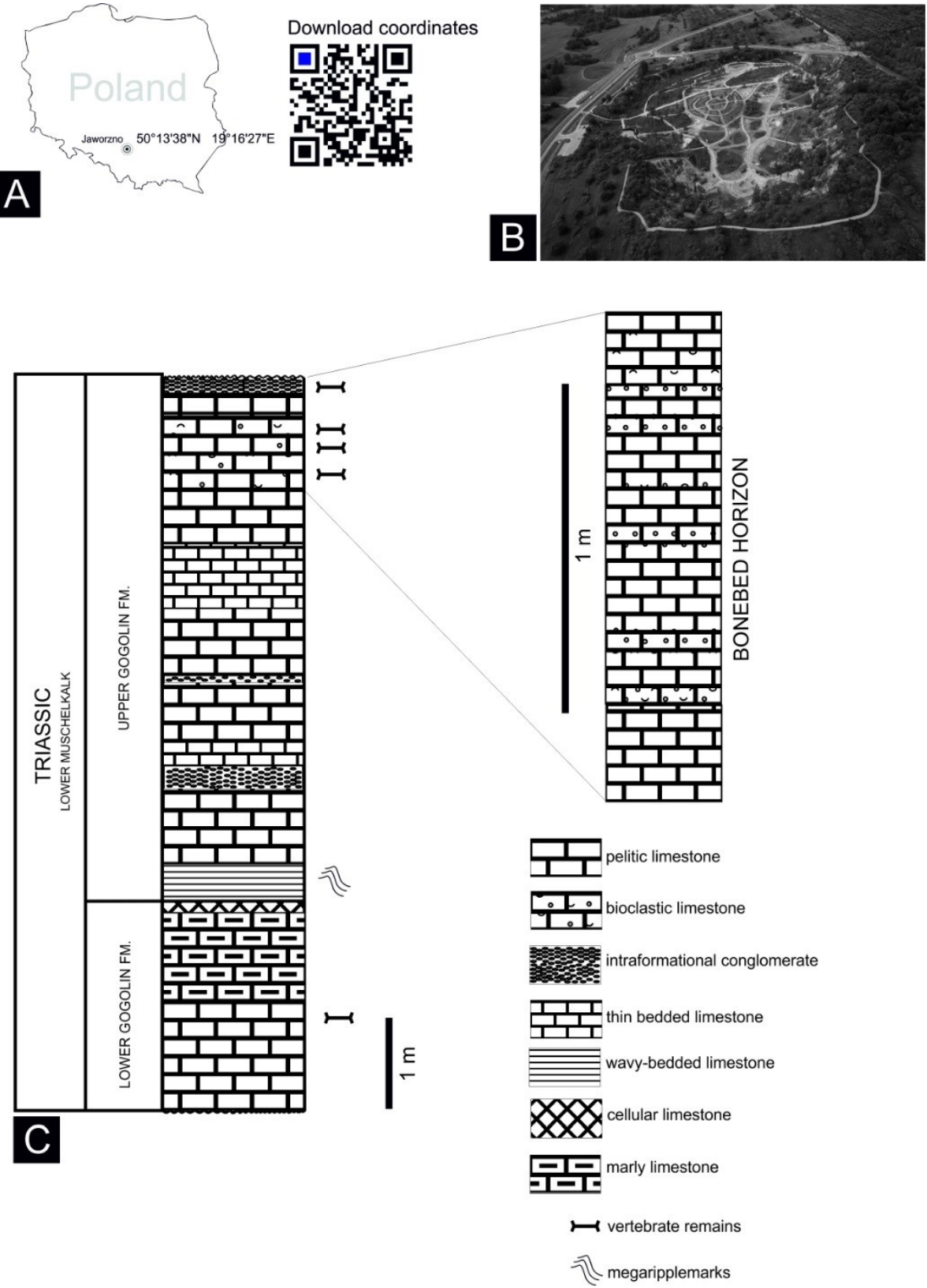

Fig.1. A) Location of the Sadowa Góra quarry in Jaworzno, southern Poland; B) An aerial photograph of the GEOsfera - Education Centre of Nature and Geology, located in the western part of the Sadowa Góra quarry (photo credit: City Hall of Jaworzno, reproduced with permission); C) Geological section of the southern wall of the Sadowa Góra quarry 
This paper focusses on one lithostratigraphic unit, limestones with Entolium and Dadocrinus, where a huge accumulation of vertebrate remains was found. According to Hagdorn and Głuchowski (1993), the Dadocrinus zone corresponds to the Lower Anisian. These limestones are mostly thin- to medium-bedded, wavy-bedded and crumpled marly pelitic, thick- to medium-bedded crinoid, and thin- to medium-bedded bioclastic limestones and intraformational conglomerates with marly intercalations consisting mainly of crinoids and bivalve shells with their debris (Kowal-Linka 2008). The shells are scattered throughout the sediment and have no preferred orientation (compare Chudzikiewicz 1983) The intraformational flat-pebble conglomerate occurs at the top of the bone beds. In many places Rhizocorallium burrows have been found together with the remains of fish, reptiles and coprolites.

The southern part of the Germanic Basin was a habitat for a variety of invertebrates (Hagdorn and Głuchowski 1993; Salamon et al. 2012, and the literature cited therein), fish (Liszkowski 1993; Chrząstek 2008) and reptiles (Rieppel and Hagdorn 1997; Chrząstek 2008; Surmik 2010a, b). The characteristic environment of the Triassic epicontinental sea indicates low-energy conditions, interrupted by many phases of high-energy pulses (Chudzikiewicz 1983; Szulc 2000).

\section{Material and methods}

We collected multiple samples of fossilized bones, ichthyolites and coprolites during fieldwork in 2012-14 in the Sadowa Góra quarry. Limestone fragments containing bone and numerous ichthyolites were treated in weak buffered carboxylic acid to remove the carbonate matrix and extract material of interest. The specimens were photographed using a Panasonic Lumix DMC-FZ38 digital camera equipped with a JJC Macro LED Ring Light 60 lamp in a shadowless tent. Pictures were processed using Adobe Photoshop CS2 and CorelDRAW Graphics Suite X6.

\section{Results}

Palaeontology.

During fieldwork, well-preserved bones, including femora, radials, coracoids, ischia, pubes, teeth, vertebrae, gastralia and ribs from the different region of the skeleton (Fig. 2) of Nothosaurus Münster 1834, were found, including one isolated bone from the temporal region of the skull. One massive specimen of placodont rib was also found. In total, several dozen nothosaur bones were found, ranging in size from 20 to almost $300 \mathrm{~mm}$. The most common types of bone were isolated vertebral centra, vertebral neural arches and ribs. Fish scales of miscellaneous genera, including actinopterygian Saurichthys Agassiz 1834, Birgeria Stensiö 1919, and numerous vertebrate coprolites from the same bone horizon were also recorded. Invertebrate fauna consisted of the very common crinoids Dadocrinus v. Meyer 1847, bivalve Entolium Meek 1865, and other molluscs and rare ophiuroids: Aspiduriella Bolette 1998 (compare Salamon and Boczarowski 2003; Salamon and Zatoń 2004; Salamon et al. 2012) and probably Ophiomusium Lyman 1869 (Fig. $3)$.

\section{Sedimentology and taphonomy.}

The mega-ripple marks (Fig. 4) exposed in the lower part of the Jaworzno quarry are evidence of tsunami backflows and indicate seismictsunami succession interrupting quiet, lowenergy sedimentation (Szulc 2000; see also Hagdorn and Szulc 2007). Tsunami and storm events as well as currents and waves during normal weather resulted in lesser or greater time-averaging of the assemblage of skeletal remains. As a consequence of normal-weather wave currents and combined currents, the 
arrangement of the long bones show a bimodal orientation, observed in some cases on the surfaces of rock layers. There is no apparent orientation in the case of flat and irregular bones, which are chaotically distributed in the bone bed. The long axes of long bones, particularly bones of the limbs, are approximately oriented in the direction of the water current transporting them, or of the bottom current generated by oscillating wave processes (compare Surmik 2010b). In several examples the mineral halos surrounding bones in fine-grained limestones are distinct (Fig. 5). Their origin is most likely associated with soft tissue decay which led to local $\mathrm{pH}$ changes and formation of these structures in relatively slow normal carbonate sedimentation. Intraformational conglomerates resulting from rapid high hydrodynamic events contain damaged and chaotically oriented bone fragments and mollusc shells along with irregularly-shaped grains formed by syndepositional erosion of partially lithified sediment.

The bone beds included in the Upper Gogolin Formation in the Sadowa Góra quarry contain principally isolated bones of one identified reptile taxon, Nothosaurus. Other indeterminate bone fragments are very small; nevertheless, they can be associated with other semi-aquatic reptiles.

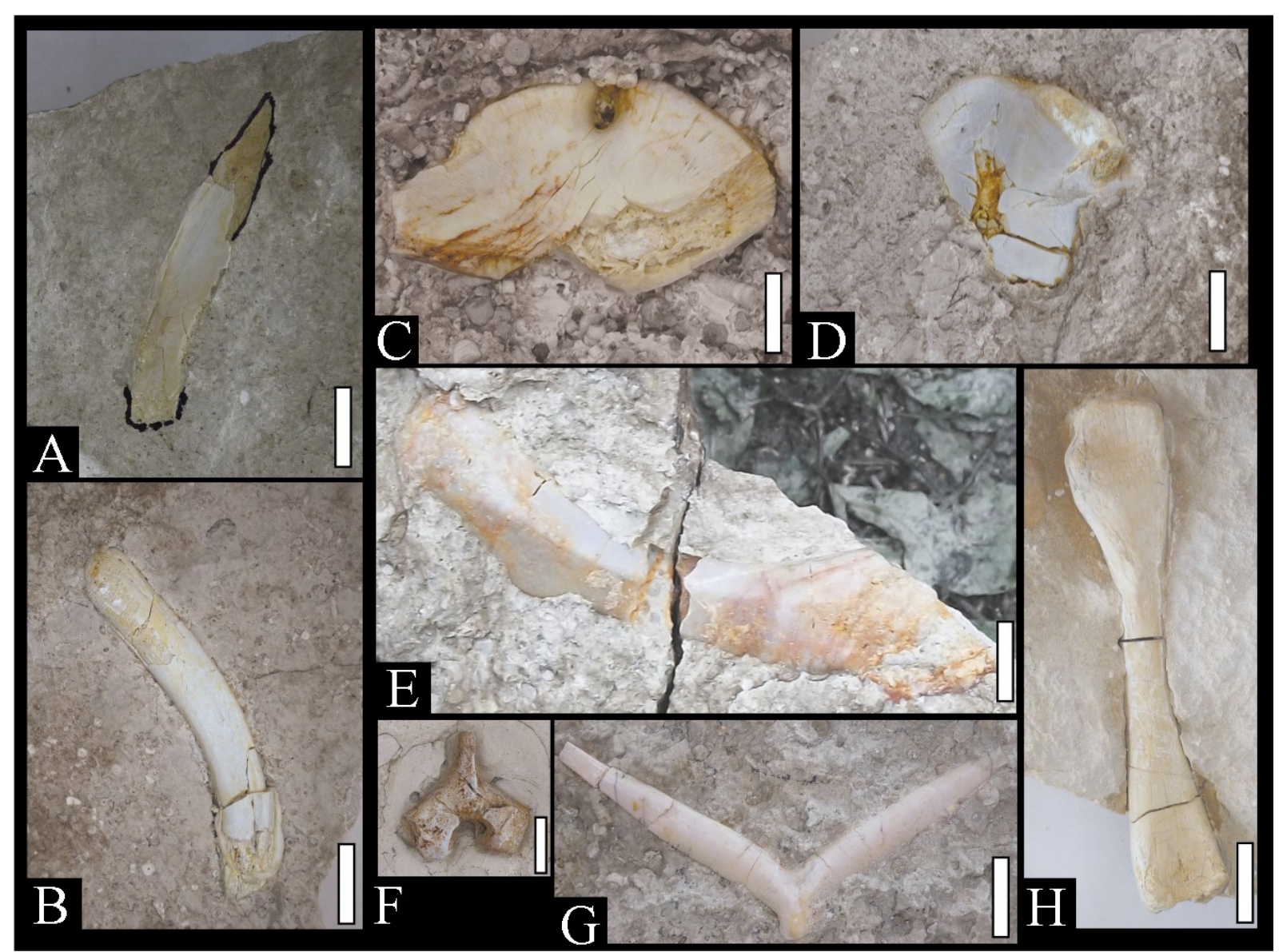

Fig.2. Specimens of Nothosaurus bones from the Sadowa Góra quarry (from fieldwork in 2012-14) - A) skull fragment from temporal region; B) tibia; C) and D) pubis; E) humerus; F) neural arch; G) gastral rib; H) femur. Scale bars equal $10 \mathrm{~mm}$. 


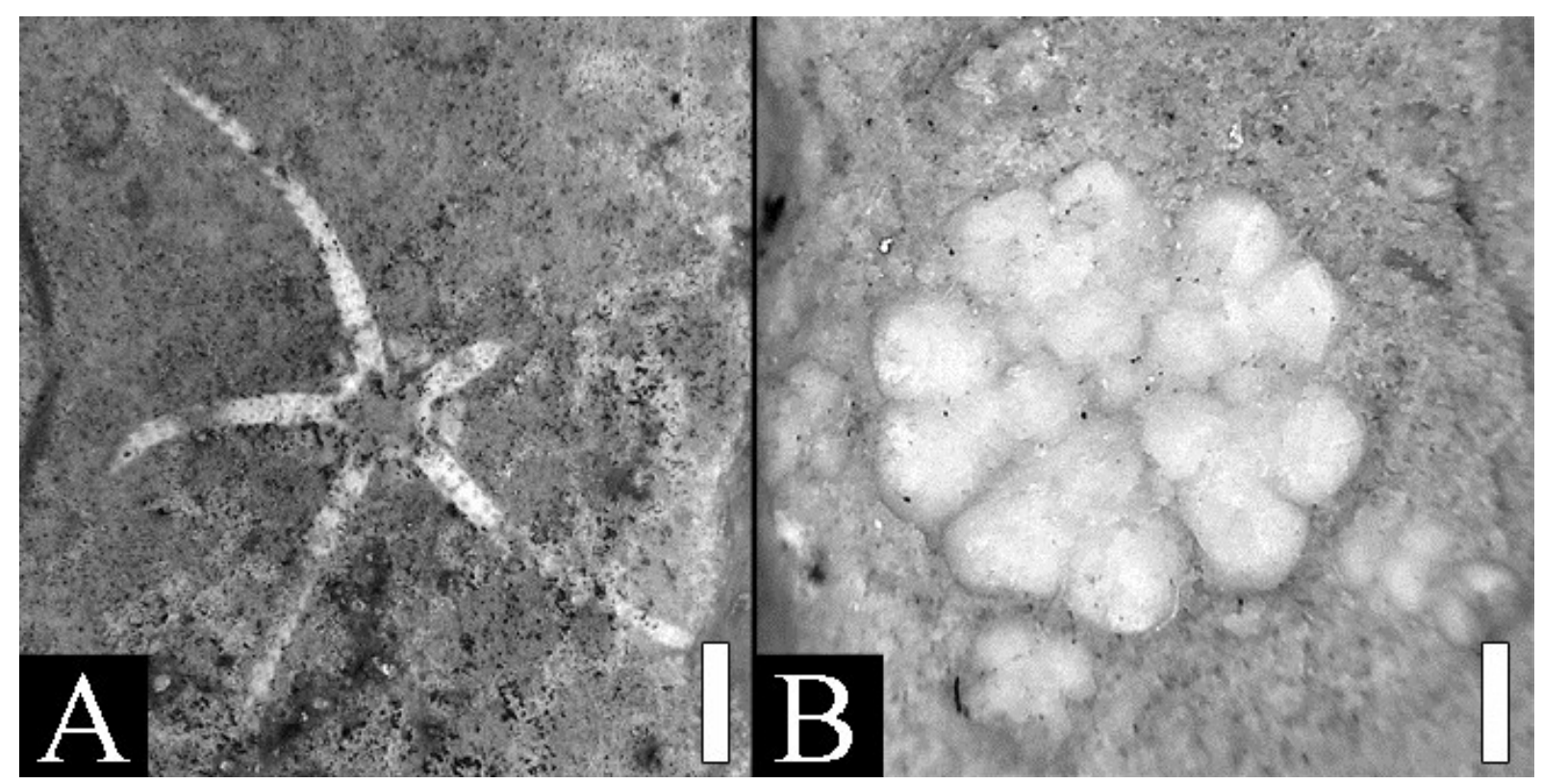

Fig.3. Specimens of ophiuroids from the Sadowa Góra quarry: A) Ophiomusium sp., scale bar equals $5 \mathrm{~mm}$. B) Aspiduriella sp. (specimen donated by Dr. Mariusz A. Salamon, University of Silesia), scale bar equals 1 $\mathrm{mm}$.

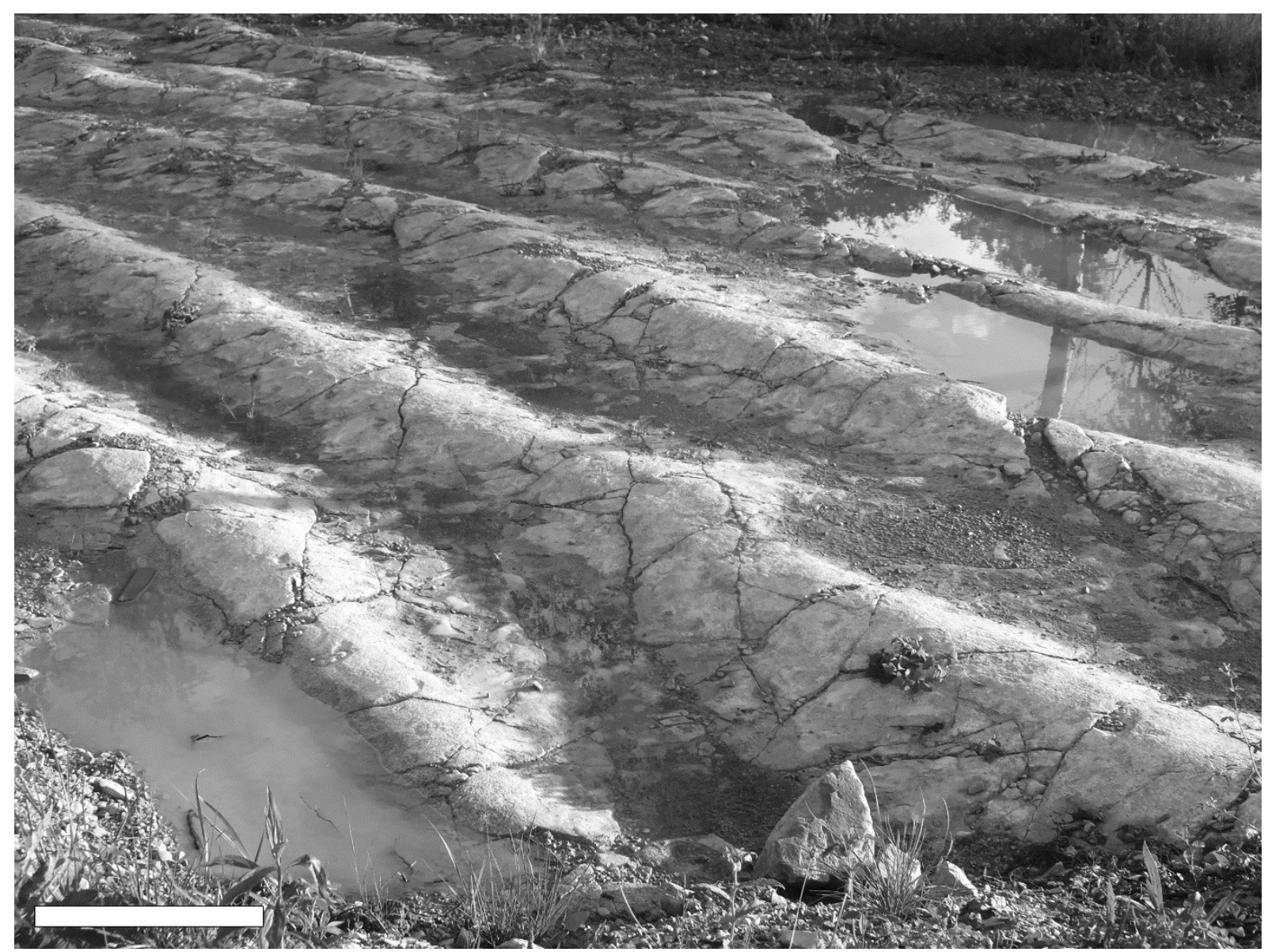

Fig.4. Mega-ripple marks occurring at the surface in several exposed places at the bottom of the Sadowa Góra quarry (photo credit: City Hall of Jaworzno, reproduced with permission). Scale bar equals $50 \mathrm{~cm}$. 


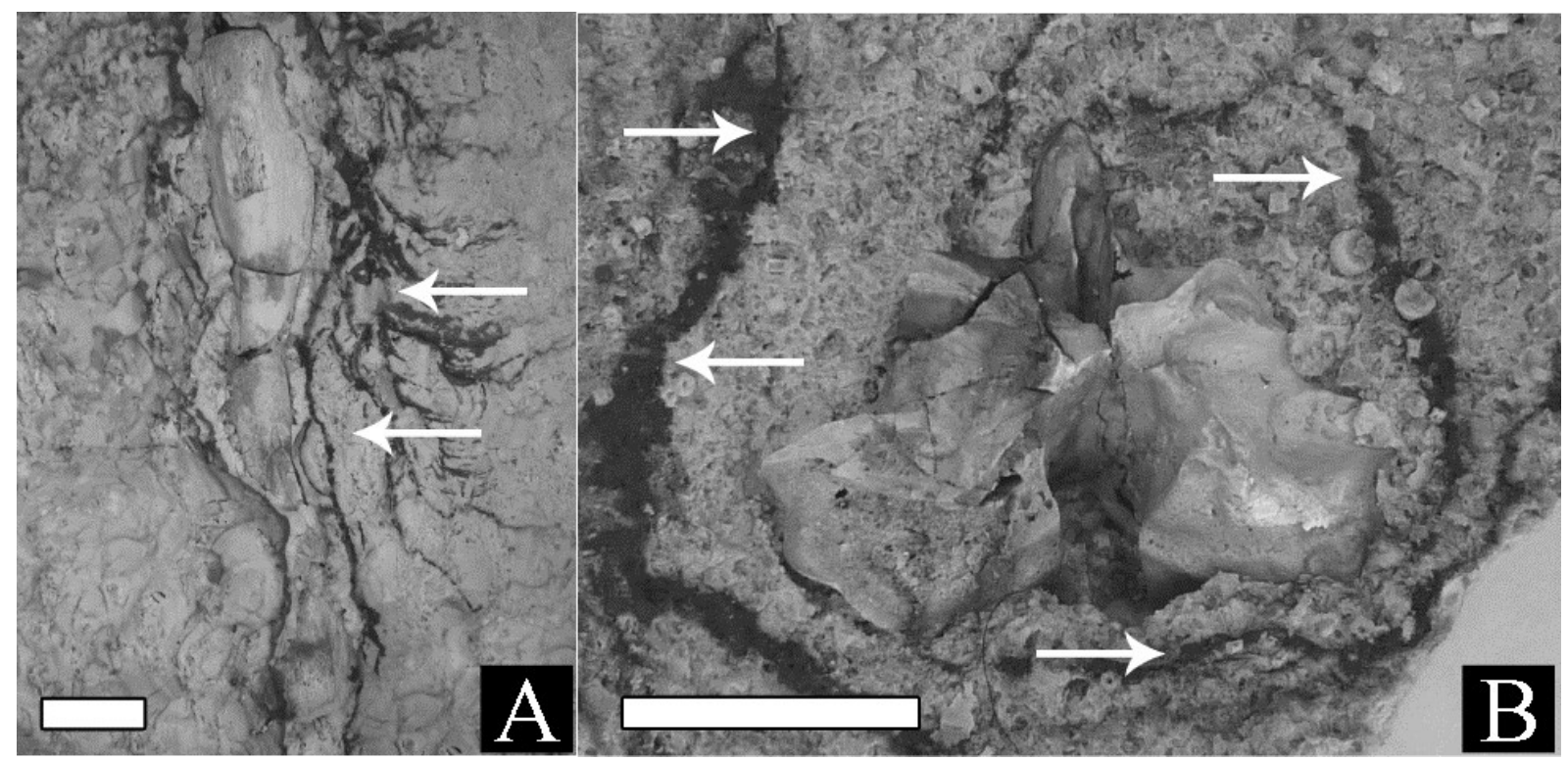

Fig.5. Ferruginous mineral halos surrounding bones, indicated by white arrows (A - femur, B - neural arch) in fine-grained limestones. Scale bars equal $10 \mathrm{~mm}$.

\section{Discussion and summary}

The Sadowa Góra quarry represents a shallowwater marine carbonate succession which is rich in remains of Middle Triassic (Anisian) vertebrates. Vertebrate bone assemblages similar in age and environmental conditions are known from the Żyglin quarry near Miasteczko Śląskie (Bardziński et al. 2008; Surmik 2010a; Kowal-Linka et al. 2014) and other fossil sites from the Central Germanic Basin (Rieppel 1995; Rieppel and Hagdorn 1997; Diedrich 2013a, b; Diedrich and Grădinaru 2013). Nothosaurid remains from the studied fossil site suggest that these animals reached up to $4 \mathrm{~m}$ in length and thus were probably apex predators, with no natural enemies.

The studied bone bed is almost monospecific and dominated by nothosaur remains, which is unusual and in contrast to other bone assemblages known from fossil localities of Upper Silesia (Bardziński et al. 2008; Surmik, 2010a). Nevertheless, environmental conditions, including timeaveraging of the fossil assemblage, are the same as in other fossil sites from Upper
Silesia. The skeletal remains were removed several times from their original burial site and subjected to secondary burial. These processes imply disarticulation of the skeletal remains, which occur mainly as isolated bones or bone fragments. The final burial of the remains took place when they were removed from the zone of active transport to a different part of the basin characterized by a distinctly hydrodynamic regime (Surmik 2010a, b).

Knowledge about the taxonomical diversity of invertebrates and vertebrates from the Middle Triassic of the Sadowa Góra quarry helped us to perform a scientific restoration of the Triassic marine ecosystem and the animals that lived there over 240 million years ago. These restorations can be seen in an indoor and outdoor exhibition in the GEOsfera Education Centre of Nature and Geology, located in the Sadowa Góra quarry (Fig. 1A, B), ul. Św. Wojciecha 100, 43-600 Jaworzno, Poland.

\section{Acknowledgments}

We would like to thank the following colleagues and officials: Agnieszka Chećko 
from the Office of Geology, City Hall of Jaworzno, for organizing social facilities during fieldwork, and Waldemar Bardziński for discussing Muschelkalk environments and sedimentology.

We also thank the reviewers for reviewing the first versions of manuscript and critical remarks. An aerial photograph (Fig. 1B) and a photograph of mega-ripple marks (Fig. 4) are reproduced with the permission of the City Hall of Jaworzno. The research project was supported by the National Science Centre (www.ncn.gov.pl), grant no. DEC2011/01/N/ST10/06989, 'Marine and terrestrial reptiles in the Middle Triassic environmental background in southern Poland'. Here is a full list of students and volunteers participating in the palaeontological fieldwork in the Sadowa Góra quarry, 2012-14 (in alphabetic order): Monika Adamczyk, Mateusz Bochenek, Ewelina Borcuch, Krzysztof Broda, Delfina Bujałkowska, Dominika Czop, Alina Dębowiec, Piotr Grabka, Zbigniew Jelonek, Przemysław Kopta, Kinga Kosylarz, Anna Łazuka, Patrycja Miara, Daria Opyd, Anna Orlik, Wojciech Pietrzak, Mariusz Simka, Dawid Surmik (fieldwork leader), Adrian Tkocz, Aleksandra Waluga, Anna Wawrzyniak, Mateusz Wolny, Maciej Zastępa, Kajetan Zięba.

\section{References}

Alexsandrowicz S.W., Aleksandrowicz Z. (1960) Triassic formations in the vicinity of Strzemieszyce and Sławków (Utwory triasowe w okolicach Strzemieszyc i Sławkowa). Biul. Inst. Geol. 152, 95-171 (in Polish).

Alexsandrowicz S.W. (1966) Stratigraphy of Triassic sediments in Byczyna near Jaworzno (Stratygrafia osadów triasowych w Byczynie koło Jaworzna). Kwart. Geol. 10, 315-326 (in Polish).

Alexandrowicz S.W. (1971) Transgressive overlap of Triassic deposits on Palaeozoic deposits between Klucze and Bydlin (Przekraczające ułożenie osadów triasowych na paleozoicznym podłożu między Kluczami a Bydlinem). Rudy i Met. Nież. 16, 468-470 (in Polish).

Alexandrowicz S.W. (1971) Lower Triassic sediments in Pilchowice near Gliwice (Osady dolnego triasu w Pilchowicach koło Gliwic). Spraw. z Pos. Kom. Nauk PAN 13, 546-550 (in Polish).

Assmann P. (1944) The stratigraphy of Uppersilesian Triassic. Part 2. The Muschelkalk (Die Stratigraphie der oberschlesischen Trias. Teil II. Der Muschelkalk). Abhandlungen des Reichsamtes für Bodenforschung, Berlin, New edition (in German).

Bardziński W., Surmik D., Lewandowski M. (2008) Middle Triassic vertebrate site near Żyglin in Lower Silesia (Stanowisko kręgowców środkowego triasu koło Żyglina na Górnym Śląsku). Prz. Geol. 56, 532-536 (in Polish).

Bogacz K., Dżułyński S., Gradziński R., Kostecka A. (1968). Origin of crumpled limestone in the Middle Triassic of Poland. Rocz. Pol. Tow. Geol. 38, 385-394.

Bojkowski K. (1955) The Lower Muschelkalk in the vicinity of Szczakowa (Dolny wapień muszlowy w okolicy Szczakowej). Biul. Inst. Geol. 97, 229-270 (in Polish).

Chrząstek A. (2008) Vertebrate remains from the Lower Muschelkalk of Raciborowice Górne (North-Sudetic Basin, SW Poland). Geological Quarterly 52, 225-238.

Chudzikiewicz L. (1975) Intraformational conglomerates in the Gogolin Beds (Middle Triassic, Southern Poland). Rocznik Polskiego Towarzystwa Geologicznego, XLV, 3-20.

Chudzikiewicz L. (1983) Sedimentation of the Gogolin Beds of the eastern rim of the Upper Silesian Basin (Sedymentacja warstw gogolińskich wschodniego obrzeżenia Zagłębia Górnośląskiego). 
Studia Geologia Polonica 75, 7-59 (in Polish).

Diedrich C. (2013a) Shallow marine sauropterygian reptile biodiversity and change in the Bad Sulza Fm (Illyrian, Middle Triassic) of Central Germany - and a contribution to the evolution of Nothosaurus in the Germanic Basin. New Mexico Museum of Natural History and Science 61, 132-158.

Diedrich C. (2013b) Marine pachypleurosaur Serpianisaurus germanicus nov. spec. remains from the late Pelsonian (Middle Triassic) of the Germanic Basin in Europe. New Mexico Museum of Natural History and Science 61, 159-168.

Diedrich C., Grădinaru E. (2013) Distribution of basal Middle Triassic fossil reptile placodonts in the Germanic Basin and northern Tethys. New Mexico Museum of Natural History and Science 61, 216-227.

Kubicz A., Dżułyński S. (1971) Recrystallized and disaggregated limestones in the Triassic of Silesia. Ann. Soci. Geolog. Pol. $41,519-530$

Ekiert F. (1959) The Boleslaw mine deposit viewed against the background of the geology of the area between Sławków and Olkusz (Złoże kopalni Bolesław na tle geologii obszaru pomiędzy Sławkowem i Olkuszem). Biul. Inst. Geol. 101, Warszawa (in Polish)

Gruszczyk H. (1956) Observations on the formation of Triassic Cracow-Silesia marine deposits (Uwagi w sprawie wykształcenia morskich utworów triasu śląsko - krakowskiego). Inst. Geol. Biul. 107, Warszawa.

Hagdorn H., Głuchowski E. (1993) Palaeobiogeography and Stratigraphy of Muschelkalk Echinoderms (Crinoidea, Echinoidea) in Upper Silesia. [In]: H. Hagdorn \& A. Seilacher (eds.) Muschelkalk. Schöntaler Symposium Hagdorn H., Szulc, J. (2007) Stop III. 2. Żyglin - small active quarry. [In]: Szulc J., Becker
A. (eds.). International Workshop on the Triassic of Southern Poland: field trip guide, September 3-8, 2007: Pan-European Correlation of the Epicontinental Triassic 4th Meeting, Warszawa, 61.

Kowal-Linka M. (2008) Formalization of the lithostratigraphy of the Gogolin Formation (Middle Triassic) in Upper Silesia (Formalizacja litostratygrafii formacji gogolińskiej (trias środkowy) na Śląsku Opolskim), Geologos 14, 125-161 (in Polish)

Kowal-Linka M. (2009) New lithostratigraphic units in the hierarchy of layers within the Gogolin Formation (Middle Triassic) in Upper Silesia (Nowe jednostki litostratygraficzne $\mathrm{w}$ randze warstw $\mathrm{w}$ obrębie formacji gogolińskiej (trias środkowy) na Śląsku Opolskim). Geologia 35, 153-174 (in Polish).

Kowal-Linka M., Jochum K.P., Surmik D. (2014). LA-ICP-MS analysis of rare earth elements in marine reptile bones from the Middle Triassic bone bed (Upper Silesia, S Poland): Impact of long-lasting diagenesis, and factors controlling the uptake. Chemical Geology 363, 213-228.

Kuźniar C. (1930) Zinc and lead deposits in Jaworzno and Długoszyn (Złoża cynku i ołowiu w Jaworznie i Długoszynie). Państwowy Instytut Geologiczny, Posiedz. Nauk., 25 (in Polish).

Liszkowski J. (1993) Selachii fauna of Muschelkalk of Poland: composition, stratigraphy and paleoecology (Die Selachierfauna des Muschelkalks in Polen: Zusammensetzung, Stratigraphie und Paläoökologie). [In:] Schöntaler Symposium (eds. H. Hagdorn and A. Seilacher). Sonderbände der Gesellschaft für Naturkunde Württemberg, Goldschneck, Stuttgart, 2, 175-185 (in German).

Narkiewicz K., Szulc J. (2004) Controls on migration of conodont fauna in peripheral oceanic areas - an example from the 
Middle Triassic of the Northern PeriTethys. Geobios 37, 425-436.

Nawrocki J., Szulc J. (2000) The Middle Triassic magnetostratigraphy from the Peri-Tethys basin in Poland. Earth and Planetary Science Letters 182, 77-92.

Niedźwiedzki R. (2000) Lithostratigraphy of the Górażdżański and Dziewkowicki formations in Opole Silesia (Litostratygrafia formacji górażdżańskiej i formacji dziewkowickiej na Śląsku Opolskim). Prace GeologicznoMineralogiczne 71, 1-72 (in Polish).

Rieppel O. (1995) Fragmenta Sauropterygiana. Neues Jahrbuch für Geologie und Palaeontologie. Abhandlungen, 197, 383397.

Rieppel O., Hagdorn H. (1997) Paleobiogeography of Middle Triassic Sauropterygia in Central and Western Europe. [In:] Callaway, J. M. and Nicholls, E. L., (eds.) 1997: Ancient Marine Reptiles. XIVI-501 - Academic Press, San Diego.

Siedlecki S. (1949) Issues of the stratigraphy of the marine Triassic in the Cracow region (Zagadnienia stratygrafii morskich utworów triasu krakowskiego). Rocz. Pol. Tow. Geol. 18, 191-243 (in Polish).

Śliwiński S. (1964) Geology of the Siewierz region (Geologia obszaru siewierskiego). Prace geologiczne PAN 25, 1-58 (in Polish).

Śliwiński S. (1969) The development of orebearing dolomites in the Cracow-Silesia region (Rozwój dolomitów kruszconośnych $\mathrm{w}$ obszarze krakowskośląskim). Pr. Geol. PAN, Oddz. w Krakowie (Geol. Transact.) 57, 123 (in Polish).

Salamon M.A., Boczarowski A. (2003) The first record of Aspiduriella (Ophiuroidea) in the Upper Muschelkalk of Poland. Geological Quarterly 47, 307-310

Salamon M.A., Zatoń M. (2004) Massoccurrence of articulated skeletons of
Middle Triassic ophiuroids from the Upper Silesia and their taphonomical implications (southern Poland). Prz. Geol. 52, 9971001.

Salamon M.A., Niedźwiedzki R., Lach R., Brachaniec T., Gorzelak P. (2012) Ophiuroids discovered in the Middle Triassic hypersaline environment. PLoS ONE 7: e49798. doi:10.1371/journal.pone.0049798

Surmik D. (2010a) Preliminary taphonomical analysis of Lower Muschelkalk bone accumulation in Silesia (Poland). [In:] Morphology and Systematic of Fossil Vertebrates (Ed. D. Nowakowski). DN Publisher, Wrocław, 110-117.

Surmik D. (2010b) Taxonomic diversity and selected aspects of the taphonomy of marine reptiles of the Muschelkalk of Silesia (Zróżnicowanie taksonomiczne i wybrane aspekty tafonomii gadów morskich wapienia muszlowego Śląska). Dissertation, University of Silesia (in Polish).

Szulc J. (2000) Middle Triassic evolution of the northern Peri-Tethys area as influenced by early opening of the Tethys Ocean. Ann. Soc. Geol. Polon. 70, 1-48.

Woźniak P., Krzeczyńska M. (2014) Sadowa Góra quarry in Jaworzno - future under the sign of GEOsphere! (Kamieniołom Sadowa Góra w Jaworznie - przyszłość pod znakiem GEOsfery!). Prz. Geol. 62, 510-513 (in Polish).

Wyczółkowski J. (1971) The influence of the surface morphology of the Palaeozoic substrate on Buntsandstein and Lower Muschelkalk deposits (Wpływ morfologii powierzchni podłoża paleozoicznego na sedymentację osadów pstrego piaskowca i dolnego wapienia muszlowego). Biul. Inst. Geol. 243, 121-163 (in Polish).

Zawidzka K. (1975) Conodont stratigraphy and sedimentary environment of the Muschelkalk in Upper Silesia. Acta Geol Pol 25, 217-257 
Zeuschner L. (1836) Cracow Muschelkalk, its ore-bearing rocks and bone remains (Krakauer Muschelkalk, seine Erzführung und Knochenreste). Neues Jahrbuch für
Mineralogie, Geognosie, Geologie und Petrefaktenkunde, 340-342 (in German). 